Bartzen, B. A., and K. W. Dufour. 2017. Northern Pintail (Anas acuta) survival, recovery, and harvest rates derived from 55 years of banding in Prairie Canada, 1960-2014. Avian Conservation and Ecology 12(2):7. https://doi.org/10.5751/ACE-01048-120207

Copyright (C) 2017 by the author(s). Published here under license by the Resilience Alliance.

Research Paper

\title{
Northern Pintail (Anas acuta) survival, recovery, and harvest rates derived from 55 years of banding in Prairie Canada, 1960-2014
}

\author{
Blake A. Bartzen ${ }^{1}$ and Kevin W. Dufour ${ }^{1}$ \\ ${ }^{1}$ Canadian Wildlife Service
}

\begin{abstract}
Northern Pintail (Anas acuta; hereafter pintail) experienced a significant population decline in North America in the 1980s but did not rebound to the previous population level the way that other prairie dabbling duck species (Anas spp.) did once habitat conditions improved. Although the population decline occurred throughout the breeding range of pintails, the decline was most pronounced and sustained in Prairie Canada, i.e., southern Alberta and Saskatchewan. Thus, we estimated and examined annual survival, recovery, and harvest rates of pintails banded in Prairie Canada from 1960-2014. Annual survival rates varied by sex but were relatively high compared to those of other dabbling duck species and increased slightly over the study period to end at $0.64 \pm 0.13$ (SE) and $0.74 \pm 0.10$ for females and males, respectively. Recovery and harvest rates varied over time but generally declined in the $1980 \mathrm{~s}$ and increased from the early 1990s until the end of the study period. There was no clear evidence that hunting bag limit restrictions affected annual survival, recovery, or harvest rates. In addition, we could find no compelling evidence that harvest mortality was substantially additive to nonharvest mortality for pintails. However, we could not definitively ascertain the effects of the restrictions, and we suggest that a trial basis of liberalized hunting bag limits would do much to improve the understanding of harvest and population dynamics of pintails and pose little risk to the population. Based on our results, we believe that measures other than harvest restrictions will likely have to be taken to elevate the pintail population to the North American Waterfowl Management Plan objective.
\end{abstract}

\section{Estimation des taux de survie, de récupération de bagues et de récolte du Canard pilet (Anas acuta) à partir de 55 ans de données de baguage dans les Prairies canadiennes, 1960-2014}

RÉSUMÉ. La population de Canard pilet (Anas acuta; ci-après pilet) a subi une baisse importante en Amérique du Nord dans les années 1980 et n'a pas retrouvé son niveau antérieur comme cela s'est pourtant produit pour les autres espèces de canards de prairie (Anas sp.) une fois que les conditions d'habitat se sont améliorées. Bien que la baisse de population soit survenue dans l'ensemble de l'aire de nidification du pilet, elle a été plus prononcée et durable dans les Prairies canadiennes, c'est-à-dire le sud de l'Alberta et de la Saskatchewan. Nous avons estimé et examiné les taux de survie annuelle, de récupération de bagues et de récolte de pilets bagués dans les Prairies canadiennes de 1960 à 2014. Les taux de survie annuelle ont varié selon les sexes et étaient relativement élevés comparativement à ceux d'autres espèces de canards barboteurs. Ces taux ont aussi légèrement augmenté au cours de la période d'étude, atteignant à la fin 0,64 $\pm 0,13$ (erreur-type) et $0,74 \pm 0,10$ respectivement pour les femelles et les mâles. Les taux de récupération de bagues et de récolte ont varié au fil des ans, mais ont de façon générale diminué dans les années 1980, puis augmenté du début des années 1990 jusqu'à la fin de la période d'étude. Nous n'avons pas observé d'effets clairs des restrictions de quotas de chasse sur la survie annuelle, la récupération de bagues et la récolte. De plus, nous n'avons pas pu trouver d'indices comme quoi la mortalité par la chasse s'avérait grandement additive aux mortalités attribuables à d'autres sources pour les pilets. Toutefois, nous n'avons pas pu déterminer avec certitude les effets des restrictions et nous croyons qu'une libéralisation des quotas, à titre d'essai, aiderait sans doute à améliorer la compréhension de la récolte et de la dynamique de population du pilet, tout en posant un faible risque pour la population. Selon nos résultats, nous pensons que des mesures autres que les restrictions sur la récolte devront vraisemblablement être prises si on veut que la population de pilets atteigne l'objectif du Plan nord-américain de gestion de la sauvagine.

Key Words: Anas acuta; annual survival; banding; harvest; Northern Pintail; Prairie Canada; recovery rates

\section{INTRODUCTION}

Northern Pintail (Anas acuta; hereafter pintail) is a medium-sized duck that occurs and breeds throughout much of northern Europe, Asia, and North America (Clark et al. 2014). Because of its large range and relatively high abundance, pintail is not considered threatened globally (BirdLife International 2016). However, in North America, pintails are of concern to conservationists because the population is currently below the desired level of the North American Waterfowl Management Plan (NAWMP; North American Waterfowl Management Plan 2014). Prior to the 1980s, the abundance of pintails in North America generally varied with the number of May ponds in the breeding areas, i.e., the abundance of ponds estimated from the spring Waterfowl Breeding Population and Habitat Survey (WBPHS; Smith 1995, Miller and Duncan 1999). Similar to many North American duck species, pintails experienced a significant 
population decline in the 1980s. However, unlike most other duck species, the pintail population did not return to previously high levels when water conditions improved; rather, the abundance of pintails appeared to have become decoupled from the number of May ponds (Miller and Duncan 1999, Podruzny et al. 2002). As a result, pintails have been the focus of much research to elucidate the factors that caused the population decline and are preventing the population from returning to previous levels.

Although population declines of pintails occurred throughout the breeding range in North America, the decline was most pronounced and sustained in southern Alberta and Saskatchewan, a core breeding area of pintails for both the midcontinent and Pacific flyway populations (Fig. 1). Survival, migration, and productivity are all important factors that determine population abundance, but adult survival can have the largest influence on population dynamics (Johnson et al. 1992, Flint et al. 1998, Richkus et al. 2005). Most of the land base in southern Alberta and Saskatchewan is dominated by agriculture in the form of crops or pasture, and natural areas are composed mainly of grasses, woods, and wetlands. Climate in the region is characterized by significant spatial and annual variation in temperature and precipitation. Unique changes in agricultural practices or climate in Prairie Canada may have had a disproportionately negative effect on the survival of pintails breeding in that region (Bethke and Nudds 1995). Predators can affect not only nest success but also adult survival, especially for nesting females (Richkus et al. 2005). It is possible that changes in predator assemblages that have occurred in Prairie Canada have led to declines in survival. In addition, pintails from Prairie Canada could be subject to unique harvest pressures. Hunting seasons in Prairie Canada generally begin earlier than those in the United States, exposing pintails in Prairie Canada to pressure from harvest for a longer period. In addition, pintails from Prairie Canada may migrate earlier than pintails from other regions, thus exposing them to early season harvest pressure not experienced by pintails from other regions (e.g., Nicolai et al. 2005). Survival and band recovery rates of pintails from other regions and at the continental scale have been estimated and documented (Nicolai et al. 2005, Fleskes et al. 2007, Rice et al. 2010), but we are not aware of any study examining survival and recovery rates specific to pintails from Prairie Canada, although that is where the population decline has been most pronounced and sustained.

Because of the population decline, pintails have been a focus of concern for waterfowl harvest management, leading to actions in Canada and the United States such as reduced hunting bag limits and season lengths; restrictive harvest regulations were brought into place during the mid- to late 1980s throughout most of Canada and the United States (Rice et al. 2010). Although regulations have been liberalized to some extent in recent years, they generally remain more restrictive than they were prior to the late 1980s. Following the trend of the population, annual harvest of pintails declined from the late 1970s, through the 1980s, and into the early 1990s; subsequently, harvest generally increased but still remained below levels of the 1970s and early 1980s (Fig. 1; Gendron and Smith 2016, U.S. Fish and Wildlife Service 2016). Whether mortality related to harvest is additive or compensatory to nonharvest mortality has been the focus of much research and debate (Anderson and Burnham 1976, Sedinger and Herzog 2012, Cooch et al. 2014). Under additive mortality models, the
Fig. 1. Population abundance of Northern Pintail (Anas acuta) in the Traditional Survey Area (TSA) of the Waterfowl Breeding Population and Habitat Survey in North America (left axis). Also shown are annual harvest estimates of Northern Pintail derived from the Canadian and U.S. national harvest surveys (right axis). "Southern AB and SK" includes abundance estimates from prairie survey strata (strata 26-35) of Alberta (AB) and Saskatchewan (SK); "Remainder of TSA" includes abundance estimates from survey strata in Alaska, Manitoba, Montana, northern Alberta, northern Saskatchewan, Northwest Territories, North Dakota, South Dakota, and western Ontario (strata 1-18, 20-25, 41-50, and 75-77); "Harvest" includes estimates of harvest in Alberta, Saskatchewan, and states from the Central, Mississippi, and Pacific Flyways.

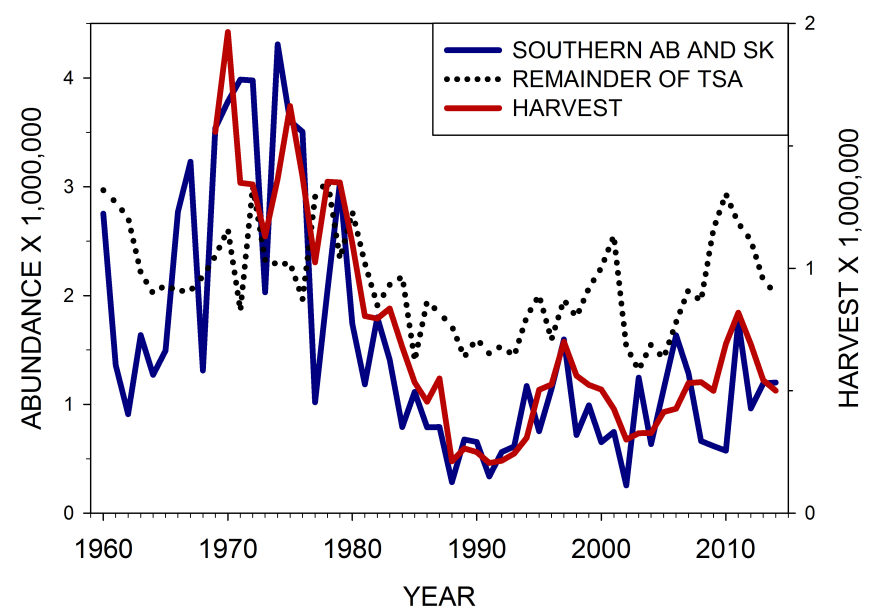

probability of mortality related to hunting and nonhunting sources are added together to estimate the total probability of mortality and, conversely, survival. Under compensatory mortality models, there is a threshold of hunting mortality under which changes in harvest have no apparent effect on survival probability. Banding and corresponding recovery data can be used to estimate parameters important to management such as annual survival, recovery, and harvest rates (White and Burnham 1999). Estimating these parameters and understanding why they vary can aid managers in determining the effectiveness of management actions and whether modifications are needed. With regard to harvest regulations, one can monitor the aforementioned rates during periods of regulation change to determine if regulations may be affecting survival and, in turn, population abundance (e.g., Alisauskas et al. 2011, Arnold et al. 2016).

Although annual survival is known to be a key parameter affecting population abundance, survival rates specific to pintails of Prairie Canada have not been examined to determine whether there was a decline in survival coinciding with the decline in the population. Consequently, our objectives were: (1) to use banding and recovery data of pintails banded in Prairie Canada to estimate annual survival, recovery, and harvest rates, (2) to quantify changes (trends) in these estimates over time, (3) to evaluate the effect of hunting bag limit restrictions on survival and recovery rates, and (4) to determine if harvest mortality is additive or compensatory 
to nonharvest mortality. Adult females of some ducks and other bird species tend to have lower survival rates than males because of increased vulnerability and energy investment associated with nesting and brood rearing (Johnson et al. 1992). In addition, survival tends to be lower in juveniles because they are more susceptible to harvest, predators, disease, and weather-related mortality (Baldassare 2014). As a result, we predicted that annual survival rates of pintails from Prairie Canada would vary by age and sex, with greater survival of males than females and of adults than juveniles. Although previous studies did not detect trends in survival rates over time (Nicolai et al. 2005, Rice et al. 2010), we anticipated there would be a declining trend for Prairie Canada coinciding with the population decline of the 1980s and that survival would generally be lower for pintails banded in Prairie Canada than pintails from other regions. During wet years, more females attempt nesting but there is more food and habitat available to males, so we anticipated that survival rates would vary with water conditions: adult female survival would be lower and adult male survival would be greater in years when conditions were wetter in Prairie Canada (Nichols et al. 1982, Dufour and Clark 2002). For many dabbling duck species, harvest rates tend to be greater for males than females and for juveniles than adults, and we expected this pattern to hold for pintails from Prairie Canada. In addition, we hypothesized that there would be an effect of harvest regulations on survival, recovery, and harvest rates, with survival increasing and recovery and harvest rates decreasing with more restrictive harvest regulations (Smith and Reynolds 1992, Rice et al. 2010). Finally, because we anticipated an effect of harvest regulations on annual survival rates, we predicted that harvest mortality would be additive to some degree to nonharvest mortality.

\section{METHODS}

Our sample comprised pintails banded at locations in Alberta and Saskatchewan from $54^{\circ} \mathrm{N}$ latitude south to the U.S. border because this area encompasses the so-called prairie survey strata of the WBPHS and the core breeding area for pintails in Prairie Canada (Fig. 2). The time series for our analysis began in 1960 because pintails were more abundant in the years leading up to the 1980 s, serving as a baseline measure, and the number of pintails banded annually was higher and more consistent from 1960 onwards (Fig. 3). The majority of pintails was captured using bait traps, but some drive trapping and rocket netting did occur (Cox and Afton 1998, Dieter et al. 2009). There were 274 unique locations (nearest $10^{\prime}$ block) where pintails were banded from 1960-2014, with more than half of those sites $(N=166)$ being used for banding for more than one season (Fig. 2). Although $\leq$ 100 pintails were banded annually at most sites $(N=208),>500$ pintails were banded consistently at some locations $(N=11$; Fig. 2 ). As a result, a total of 205,747 pintails were banded in the study area from 1960-2014, with an average of $3741 \pm 1774$ (SD) pintails banded annually (Fig. 3). The ratio of hatch-year (i.e., young of the year) to adult birds banded declined over the study period ( $r$ $=-0.40, P=0.002, N=55$; Fig. 4).

Collectively, banded individuals contributed 14,634 hunter recoveries over the course of the study, of which 5898 were direct recoveries (i.e., birds recovered in the hunting season immediately subsequent to banding). The highest number of band recoveries occurred in California, but there was a shift eastward later in the
Fig. 2. Locations of banding sites for Northern Pintail (Anas acuta) in Alberta and Saskatchewan, Canada ( $\leq$ $54^{\circ} \mathrm{N}$ latitude) from 1960-2014. The colors vary by the number of seasons banding occurred at each site (top) and the mean number of Northern Pintail individuals banded per year of banding at that site (bottom). Inset shows the focal area in the context of the northern prairie region of North America.

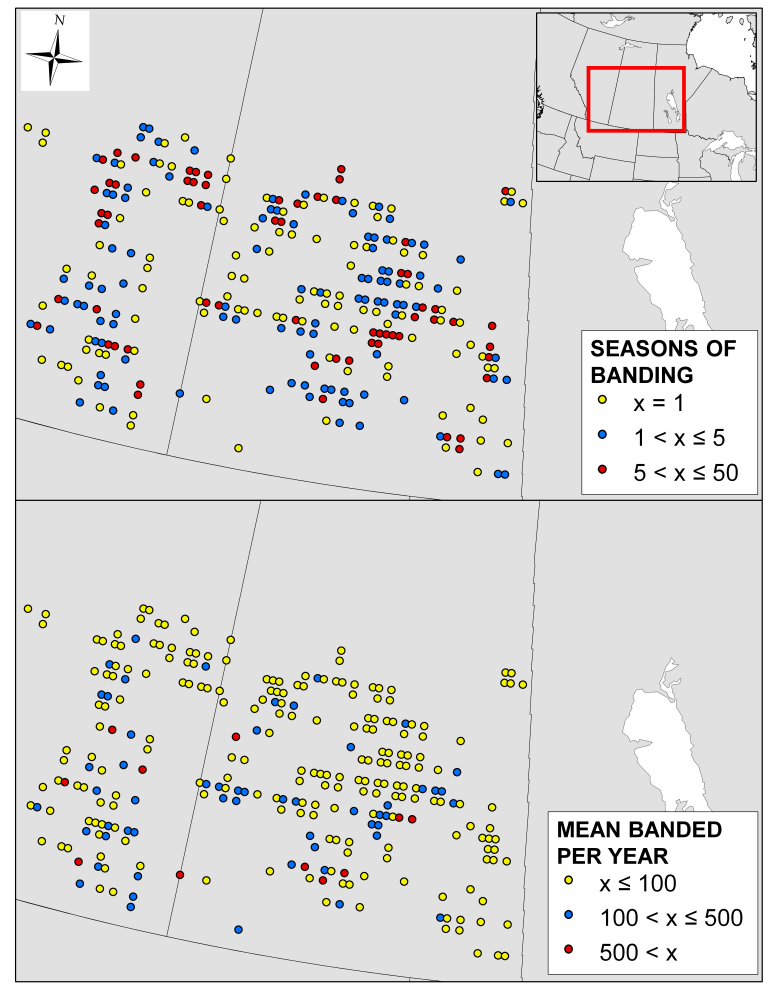

Fig. 3. Numbers of Northern Pintail (Anas acuta) banded in Alberta and Saskatchewan, Canada $\left(\leq 54^{\circ} \mathrm{N}\right.$ latitude) from 1960-2014.

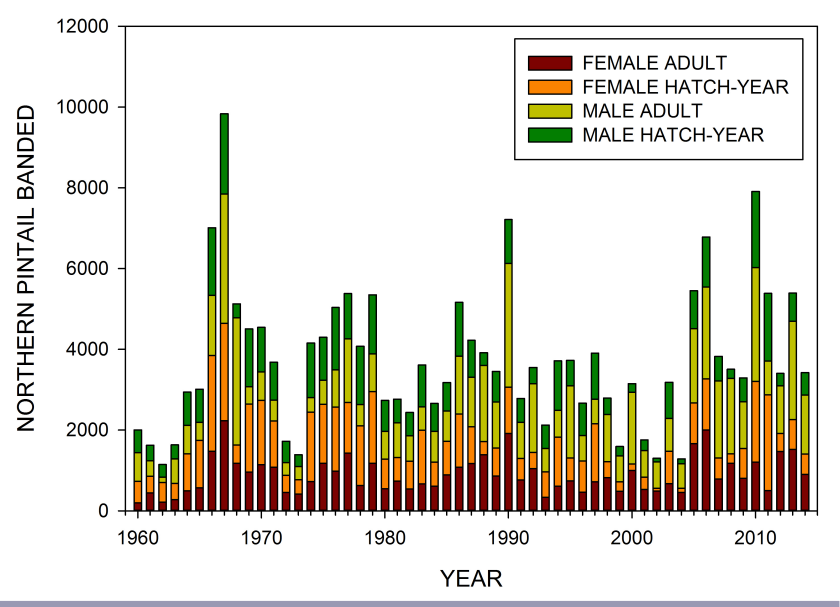


Fig. 4. Age ratio (hatch-year:adult) of Northern Pintail (Anas acuta) banded in Alberta and Saskatchewan, Canada $\left(\leq 54^{\circ} \mathrm{N}\right.$ latitude) from 1960-2014 ( $r=-0.40, P=0.002, N=55)$.

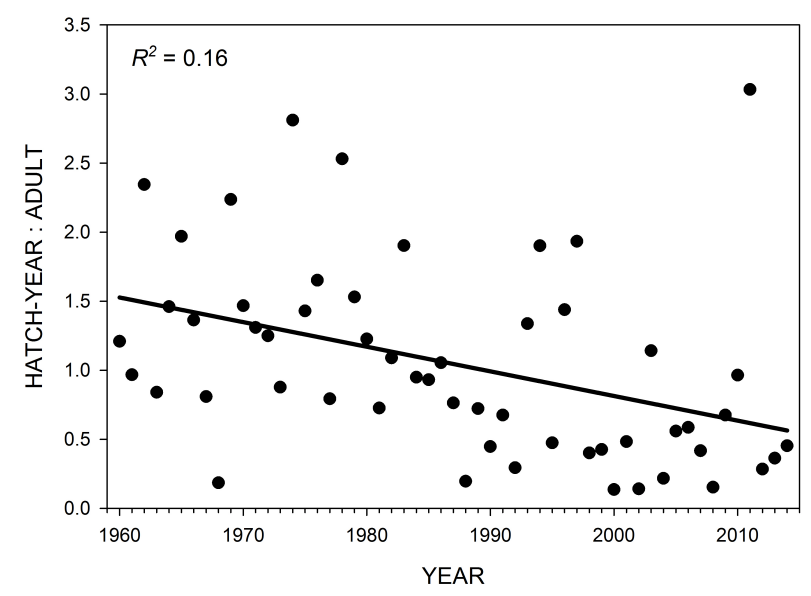

study into states along the Mississippi Alluvial Valley such as Louisiana, Arkansas, Mississippi, Missouri, Illinois, Tennessee, and Kentucky (Fig. 5). Other areas with notable increases in the proportion of total recoveries included Texas, Saskatchewan, North Dakota, and Utah. Similar to California, Alberta realized a notable decrease in recoveries over the study period.

Fig. 5. Distribution of direct band recoveries of Northern Pintail (Anas acuta) banded in Alberta and Saskatchewan, Canada $\left(\leq 54^{\circ} \mathrm{N}\right.$ latitude) from $1960-1987(N=3046)$ and 1988-2014 $(N=2852)$. Colours represent the density of recovered bands $/ 10,000 \mathrm{~km}^{2}$. Numbers shown in Saskatchewan, Alberta, Mexico, and certain U.S. states are the percentage of the total recoveries for the time period; only regions with recoveries $\geq 1 \%$ are labeled.

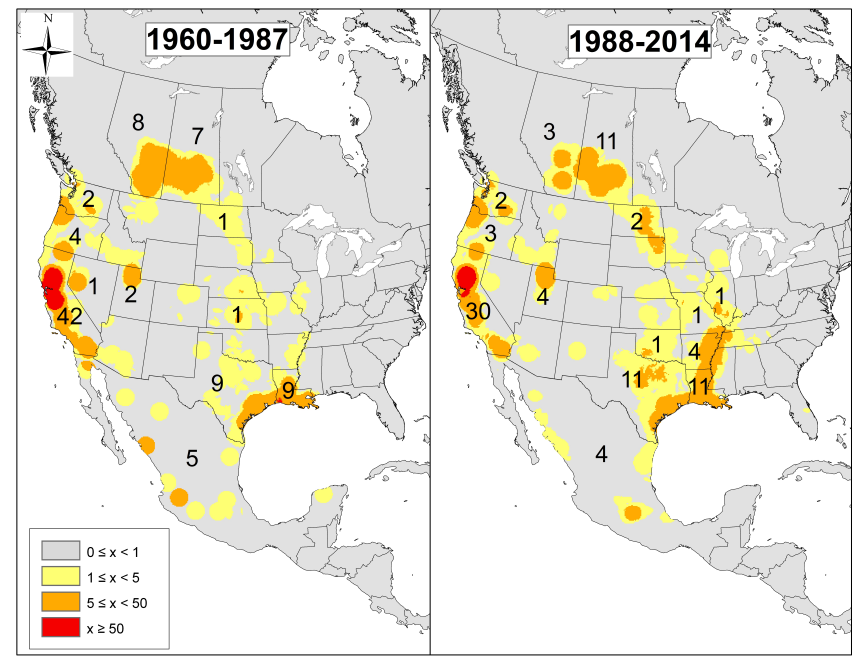

\section{Survival and recovery analysis}

We estimated rates of true annual survival $(S)$ and recovery $(f)$ using standard band-recovery models as implemented in Program MARK (Brownie et al. 1985, White and Burnham 1999). Input data for our analysis were recovery matrices involving all 205,747 individuals banded from 1960-2014, stratified according to age (adult vs. hatch-year) and sex. We developed a candidate set of models a priori based on pintail ecology, covariates of interest, and our predictions. We began with the development of a highly parameterized global model that recognized fully interactive effects of age $(a)$, sex $(s)$, and year (i.e., annual variation, denoted $t$ ) on both survival and recovery probability. Such a model yields a separate parameter estimate for each age and sex class in each year of study and is denoted $S_{\mathrm{a}^{*} *^{*}}, f_{\mathrm{a}^{*} *_{\mathrm{t}}^{*}}$. Using the median $\hat{\mathrm{c}}$-hat procedure in program MARK, we confirmed that our initial global model provided an adequate fit to the data and that overdispersion was minimal $(\hat{c}=1.0 ; 95 \% \mathrm{CI}=0.99-1.01)$. We then developed 52 reduced-parameter (constrained) models by selectively removing one or more effects from the global model. This subset of models included models that allowed age and sex classes to vary independently over time with respect to both survival and recovery probability (interactive models, denoted by *), as well as those that recognized temporal parallelism between age and sex classes (additive models, denoted by + ). In the parameter space defined by the most parsimonious model among this initial model set, we further developed models in which survival and recovery rate estimates were constrained to vary as a linear or quadratic function of calendar year (i.e., linear and quadratic time trend models, denoted $T$ and $T^{2}$, respectively) to determine if there had been long-term shifts in survival and recovery rates that would explain the population decline. In addition to the trend models, we developed competing models to examine whether there was evidence of an effect of harvest regulations on pintail survival and recovery rates. Although hunting bag limits for pintails dropped to three to five birds from 1985-1987, a bag limit of one bird was introduced in 1988 throughout most of the midcontinent and Pacific flyway jurisdictions, where substantive harvest of pintails took place (Rice et al. 2010). Bag limits and season lengths have generally been more restrictive in the United States and Canada since 1988; therefore, we considered the period prior to 1988 to be liberal and the period from 1988 onwards as restrictive in terms of regulations. Thus, we included in our candidate model set models that contrasted survival and recovery rates between the periods 1960-1987 and 1988-2014. Finally, to evaluate survival in relation to water conditions on the prairies, we included May pond abundance (https://migbirdapps.fws.gov/mbdc/databases/mas/ maydb.asp) as a time-varying group-level covariate in the analysis. In total, the final candidate set comprised 72 models.

We selected among competing models based on minimization of the Akaike Information Criterion corrected for small sample bias (AICc; Burnham and Anderson 2002). To facilitate model comparisons, we also computed AIC-based model weights $\left(w_{\mathrm{i}}\right)$, which sum to unity and provide a measure of the weight of evidence in favor of a particular model given the data (Burnham and Anderson 2002). 


\section{Harvest rates}

We calculated harvest rates for the time period 1960-2014 by first calculating the annual number of pintails banded and the number of direct recoveries (all differentiated by age and sex). The number of pintails recovered was then adjusted by band reporting rates for ducks that varied both spatially by migratory flyway and temporally (Boomer et al. 2013; R. T. Alisauskas, unpublished data). Pintails that were recovered outside of Canada and the United States were excluded from this analysis because we did not have reliable estimates of reporting rates for those areas. Finally, we divided the number of recovered birds adjusted for reporting rate by the number of birds banded to calculate harvest rates of pintails in Canada and the United States. The variance of the harvest rates was calculated using the delta method (Alisauskas et al. 2009).

To provide a direct assessment of whether harvest mortality was compensatory or additive to nonharvest mortality, we used Markov chain Monte Carlo (MCMC) methods to estimate process correlations $(\rho)$ between annual survival and recovery rates (Otis and White 2004, Sedinger et al. 2010, Arnold et al. 2016). Under this approach, if $\rho$ is negative, then harvest mortality can be assumed to be additive and is considered fully additive at $\rho \approx-1$. Conversely, harvest mortality is considered fully compensatory at $\rho \approx 0$ (Sedinger et al. 2010, Arnold et al. 2016); $\rho^{2}$ is a measure of the amount of variation in annual survival rates attributable to annual recovery rates. We conducted the MCMC analysis in MARK with the global model $S_{\mathrm{a}^{*} \mathrm{~s}_{\mathrm{t}}}, f_{\mathrm{a}^{*} \mathrm{~s}^{*} \mathrm{t}}$, and prior estimates from this model were used as initial parameter estimates for the analysis. We used 4000 iterations for model tuning, 1000 iterations as burn-in, and then stored 50,000 iterations for analysis. We specified the MCMC variance-covariance matrix, which allowed us to estimate $\rho$ between annual survival and recovery rates for each age and sex class. Furthermore, we estimated $\rho$ for two time periods for each class: 1960-1996 and 2001-2013; this allowed us to account for changes in band reporting rate associated with the introduction and full implementation of bandings of pintails in Prairie Canada that included toll-free phone numbers or web-based inscriptions (Royle and Garrettson 2005, Arnold et al. 2016).

\section{RESULTS}

\section{Survival and recovery analysis}

Model selection based on AICc indicated that the most parsimonious model was one that incorporated both a quadratic temporal trend in survival and sex differences in survival (without interaction), but no age-related variation in survival (model $S_{\mathrm{s}}$ ${ }_{\mathrm{T}}^{2}, f_{\mathrm{a}^{*}{ }^{*} \mathrm{t}} ;$ Table 1). There was little model selection uncertainty; the most parsimonious model accounted for approximately $95 \%$ of the total support among the candidate models considered $\left(w_{\mathrm{i}}=\right.$ 0.947; Table 1). Under the most parsimonious model, survival rates of males and females increased in parallel between 1960 and the late 1980s and stabilized thereafter, with male survival exceeding female survival throughout the study period (Fig. 6). At the end of the study period, survival rates $( \pm 1 \mathrm{SE})$ were 0.64 \pm 0.13 and $0.74 \pm 0.10$ for females and males, respectively. A model that included an effect of harvest regulations on survival was poorly supported by the data $\left(\triangle \mathrm{AICc}=8.90, w_{\mathrm{i}}=0.01\right.$; Table 1$)$, as were models that incorporated effects of prairie pond conditions ( $\triangle \mathrm{AICc} \geq 24.06, w_{\mathrm{i}}<0.001$; Table 1$)$.
Table 1. Summary output from competing band-recovery models developed to estimate annual survival $(S)$ and recovery $(f)$ probabilities for Northern Pintail (Anas acuta) banded in Alberta and Saskatchewan $\left(\leq 54^{\circ} \mathrm{N}\right.$ latitude) during 1960-2014. Only the 10 top-ranked models based on the adjusted Akaike Information Criterion (AICc) are shown.

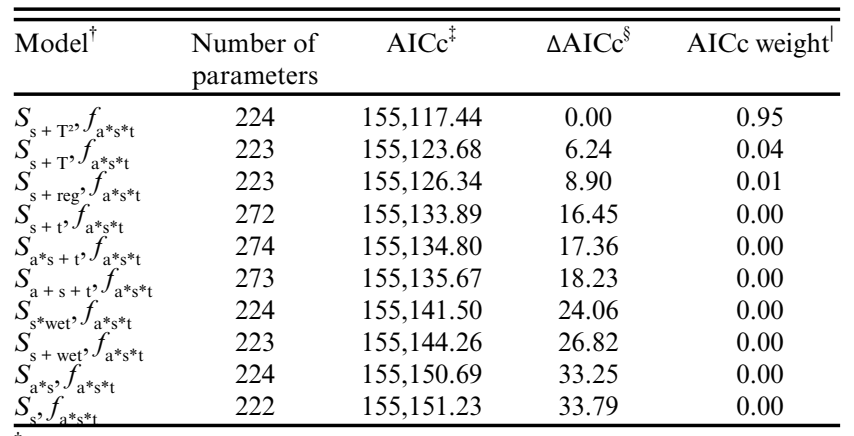

${ }^{\dagger}$ Notation follows Lebreton et al. (1992): $S=$ survival probability, $f=$ recovery probability, $a=$ age, $s=\operatorname{sex}, t=$ time (i.e., annual variation), $T$ $=$ linear time trend, $T^{2}=$ quadratic time trend, $\mathrm{reg}=$ harvest regulations (liberal vs. restrictive, i.e., pre- vs. post-1988), wet $=$ wetland conditions (May pond abundance).

${ }^{\ddagger}$ Akaike Information Criterion with small sample bias adjustment (Burnham and Anderson 2002).

${ }^{\S}$ Difference between AICc of the current model and the minimum observed value.

'Normalized Akaike weight (Burnham and Anderson 2002).

Fig. 6. Annual survival rates $(S)$ for Northern Pintail (Anas acuta) banded in Alberta and Saskatchewan, Canada $\left(\leq 54^{\circ} \mathrm{N}\right.$ latitude) from 1960-2014. Lines (upper dashed line is for males) are predicted values of $S$ from the most parsimonious model, $S_{\mathrm{s}}$ ${ }_{+\mathrm{T}}^{2}, f_{\mathrm{a}^{*} \mathrm{~s}^{*} \mathrm{t}}$, whereas point estimates are from the corresponding general model with full time-dependency in survival $S_{\mathrm{s}+\mathrm{t}}, f_{\mathrm{a}^{*} \mathrm{~s}^{*}}$. Point estimates for the interval 1960-1961 were not estimable and are not shown.

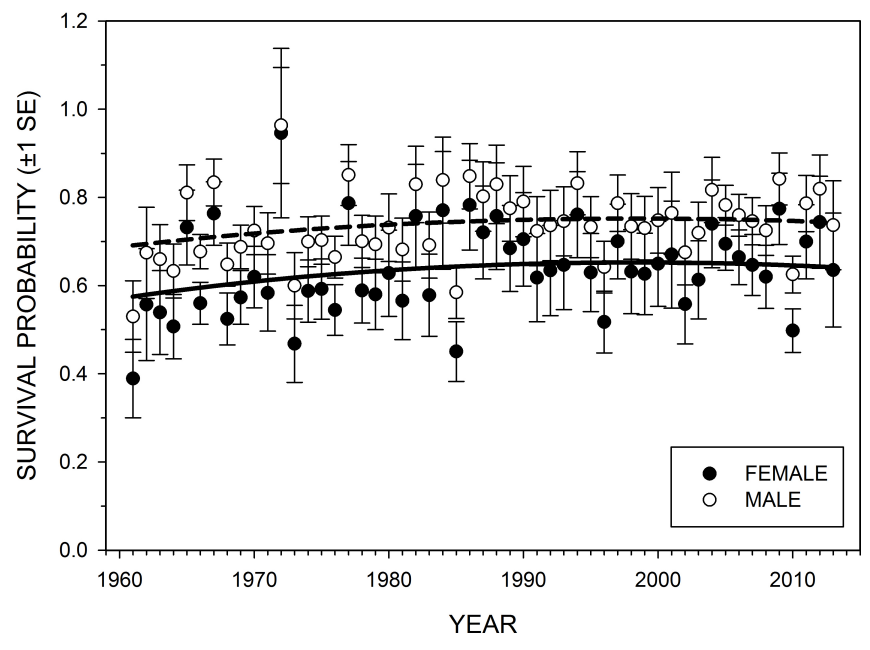


Recovery probability was best modeled to include fully interactive effects of age, sex, and time (i.e., year; Table 1). Although variable among years, recovery rates were generally lower for females than males and for adults than hatch-year birds (Fig. 7). Over all years, annual recovery rates averaged 0.015 for adult females, 0.022 for adult males, 0.033 for hatch-year females, and 0.047 for hatchyear males. Recovery rates of all four groups declined from the late 1970s into the early 1990s and then generally increased until the end of the study period in 2014 (Fig. 7). There was no evidence of an inverse association between recovery rates and restrictive harvest regulations; indeed, recovery rates generally increased during the period from 1988-2014 when restrictive regulations were in place (Fig. 7).

Fig. 7. Annual recovery rates $(f)$ for Northern Pintail (Anas acuta) banded in Alberta and Saskatchewan, Canada $\left(\leq 54^{\circ} \mathrm{N}\right.$ latitude) from 1960-2014. Estimates of $f$ are from the most parsimonious model $S_{\mathrm{s}+\mathrm{T}^{2}}, f_{\mathrm{a}^{*} \mathrm{*} * \mathrm{t}}$.

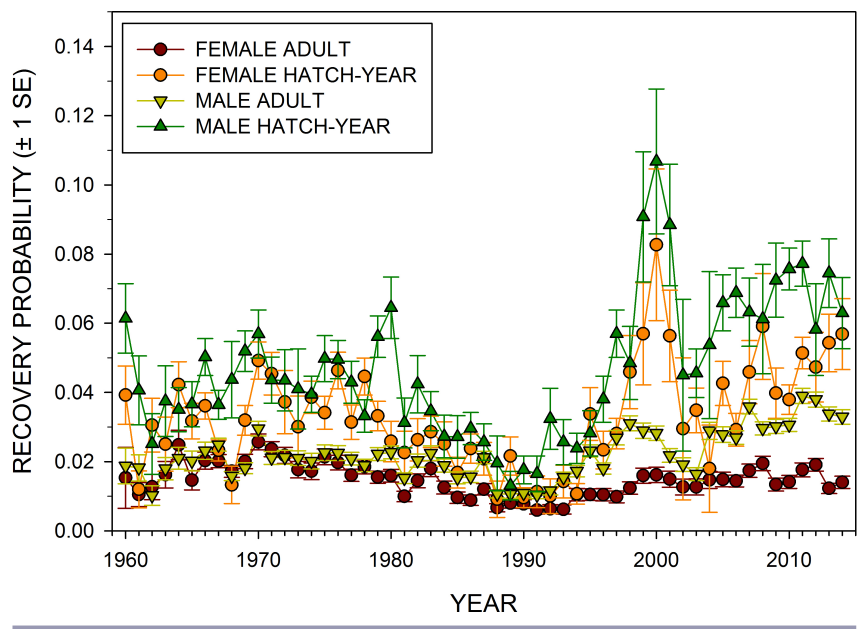

\section{Harvest rates}

When direct recoveries were adjusted for reporting rates, harvest rates generally followed a pattern similar to recovery rates: all cohorts exhibited a general decline in harvest rates from the late 1970 s to the early $1990 \mathrm{~s}$, and then harvest rates generally increased, or stabilized in the case of adult females, from that point until 2014 (Fig. 8). The 10-year average ( $\pm 1 \mathrm{SE}$ ) of harvest rates from $2005-2014$ was $2.2 \% \pm 0.5$ and $6.6 \% \pm 1.2$ for adult and hatch-year females, respectively, and $4.1 \% \pm 0.6$ and $9.3 \%$ \pm 1.4 for adult and hatch-year males, respectively. Considering the aforementioned survival rates at the end of the study period, annual mortality was $36 \%$ and $26 \%$ for females and males, respectively. Therefore, harvest accounted for no more than $6 \%$ of annual mortality for adult females, $18 \%$ of annual mortality for hatch-year females, $16 \%$ of annual mortality for adult males, and $36 \%$ of annual mortality for hatch-year males.

With the exception of adult males for the period of 1960-1996, there were no obvious negative relationships between annual survival and recovery rates (Fig. 9). Estimates of the process correlations $(\rho)$ were close to and had $90 \%$ credible intervals largely overlapping zero (Fig. 10); again, the exception was adult males from 1960-1996 $(\rho=-0.48,90 \%$ credible interval: -0.95
Fig. 8. Annual harvest rates of Northern Pintail (Anas acuta) banded in southern Alberta and Saskatchewan, Canada $\left(\leq 54^{\circ}\right.$ N latitude) from 1960-2014.

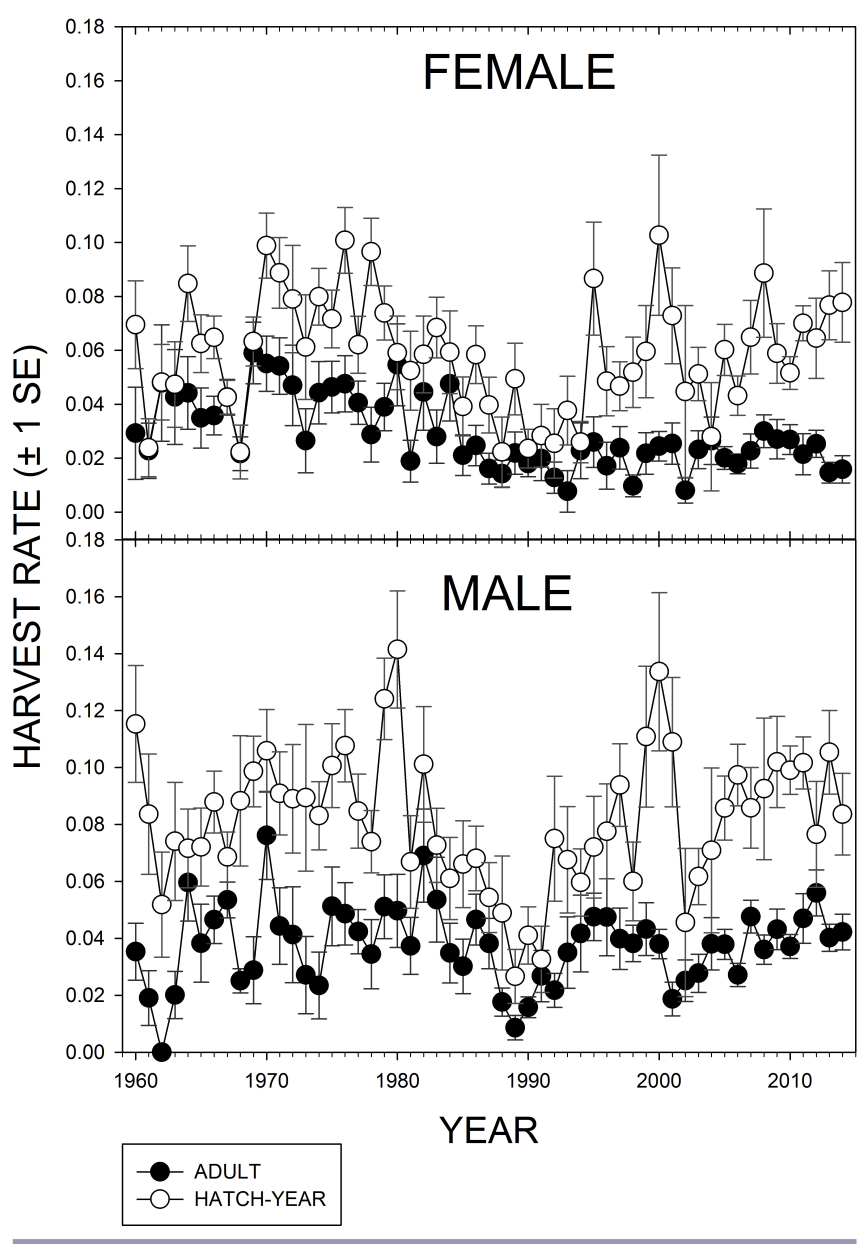

to -0.09$)$. Approximately one-quarter of the variation in annual survival rates of adult males from 1960-1996 was attributable to variation in annual recovery rates $\left(\rho^{2}=0.23\right)$, suggesting that harvest mortality was slightly additive to nonharvest mortality for that period.

\section{DISCUSSION}

Pintail survival and recovery rates in our study seem generally comparable to those in other studies of pintails (e.g., Rice et al. 2010). However, unlike the continental study (Rice et al. 2010), and contrary to our predictions, we were unable to detect agerelated variation in survival rates of pintails from Prairie Canada. In all likelihood, we were unable to detect a difference in survival rates between hatch-year and adult birds because the sample of young birds was too small in some years, resulting in imprecise estimates. With a larger sample of hatch-year birds, we would expect to detect a difference in survival rates between age classes, with adults having higher survival rates than hatch-year birds (Rice et al. 2010). However, Nicolai et al. (2005) were also unable to detect age-related differences in survival in pintails banded at the Yukon-Kuskokwim Delta, Alaska. Given the particularly pronounced 
Fig. 9. Relationships between annual survival rates $(S)$ and annual recovery rates $(f)$ for Northern Pintail (Anas acuta) banded in southern Alberta and Saskatchewan, Canada $\left(\leq 54^{\circ} \mathrm{N}\right.$ latitude) from 1960-1996 and 2001-2013. Rates were derived from the model $S_{\mathrm{a}^{*} \mathrm{~s}^{*}}, f_{\mathrm{a}^{*} \mathrm{~s}_{\mathrm{t}}}$ using the Markov chain Monte Carlo method.
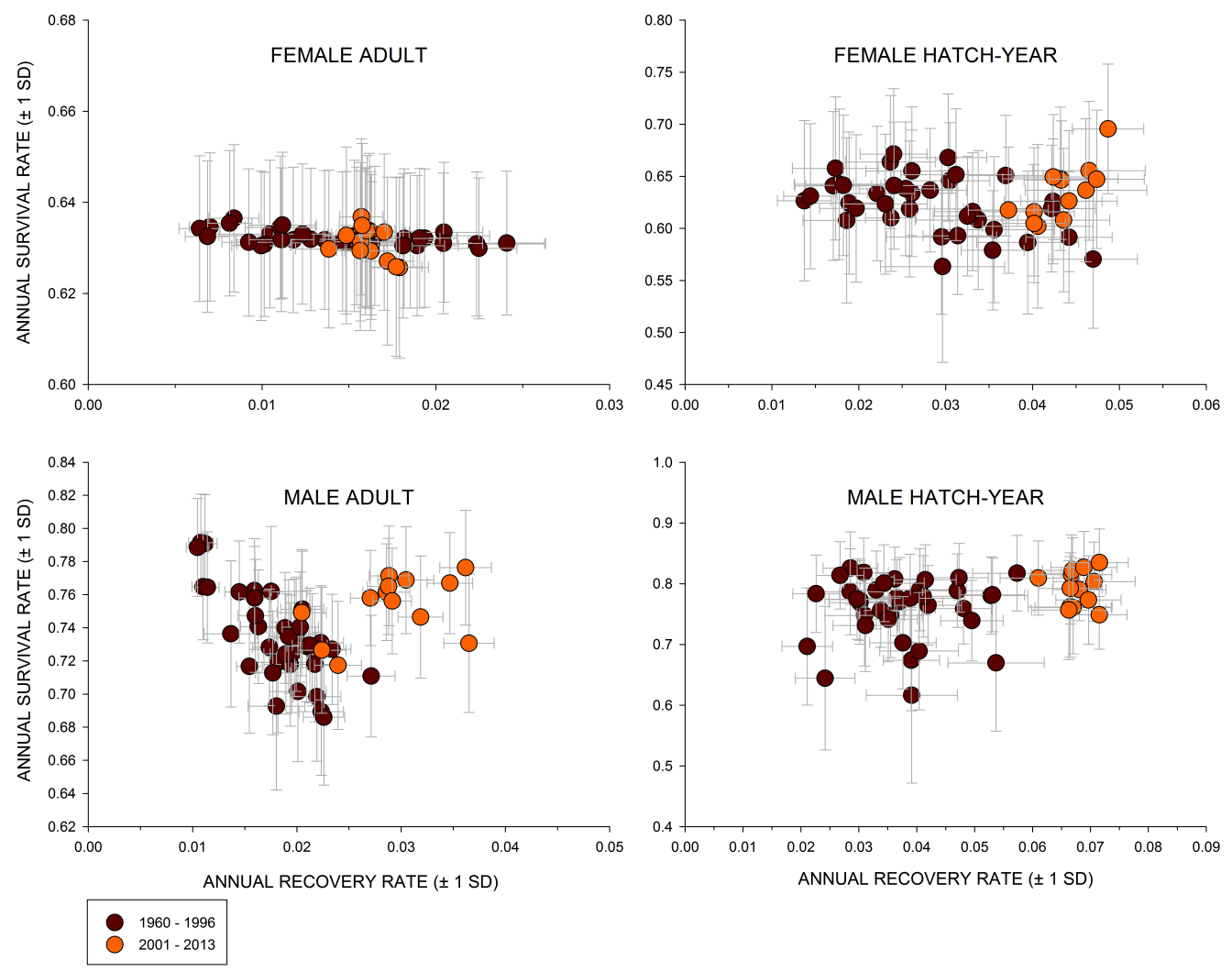

Fig. 10. Estimate of process correlations $(\rho, 90 \%$ minimum credible intervals) between annual survival rates $(S)$ and annual recovery rates $(f)$ for Northern Pintail (Anas acuta) banded in southern Alberta and Saskatchewan, Canada $\left(\leq 54^{\circ} \mathrm{N}\right.$ latitude $)$ from 1960-1996 and 2001-2013.

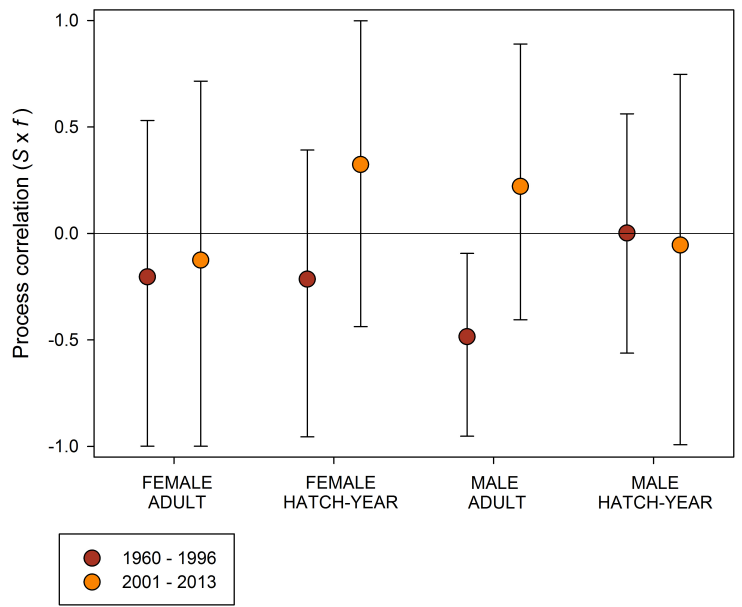

population decline of pintails in Prairie Canada, we expected to find a decline in survival for pintails from Prairie Canada if we were to detect any change at all. However, we actually detected a slight increase in survival from 1960 to 2014; other studies suggested no patterns of change in survival (Nicolai et al. 2005, Rice et al. 2010). Recovery rates generally declined during the first half of the study and increased during the latter half; with the exception of adult females, recovery rates were highest in the latter half. When we calculated harvest rates by adjusting direct recovery rates by band reporting rates, we found an increase in harvest rates in the latter half of the study, similar to recovery rates, but the change in harvest rates was not as pronounced as the change in recovery rates. Therefore, we conclude that the increase in recovery rates in the latter half of the study was a function of an increase in harvest rates, but the increase was exaggerated by the known increase in band reporting rate (Boomer et al. 2013; R. T. Alisauskas, unpublished data). Contrary to our predictions, we could find little evidence of an effect of bag limit restrictions or May pond conditions on annual survival and recovery rates of pintails.

Harvest rates were generally low for pintails from Prairie Canada, and, similar to survival and recovery rates, there was no conclusive evidence of an effect of restrictive harvest regulation measures. Harvest rates declined through the late 1970s and early 1980s, 
when regulations were generally considered liberal throughout most of Canada and the United States, and rates were lowest in the late 1980s, when harvest restrictions such as bag limit and season length reductions were implemented (Rice et al. 2010). Since the late 1980s, harvest rates were variable but generally increased despite harvest restrictions remaining in place; a possible exception to this pattern was adult females, for which harvest rates increased only slightly during the same period. It is important to consider that we excluded Mexico from our assessment of harvest rates, but based on the distribution of band recoveries and historical information, we know that a substantial amount of harvest of pintails takes place in Mexico (Kramer 1995, Miller and Duncan 1999). Consequently, our estimates of harvest rates should be thought of as a minimum and specific to Canada and U.S. harvest. To have a comprehensive estimate of harvest rates for pintails, we need a better understanding of band reporting rates for Mexico and how those rates have changed over time. Nonetheless, even with Mexico's contribution, we believe that harvest rates for pintails are likely low.

Evidence from our study suggests that harvest mortality of pintails from Prairie Canada was low, accounting for a small percentage of the annual mortality, and there is little evidence that harvest mortality was strongly additive to nonharvest mortality. However, the annual survival rates of adult males from 1960-1996 were weakly correlated with annual recovery rates. We caution that there is considerable imprecision associated with our estimates of process correlations. However, Sedinger and Herzog (2012) similarly suggest that there is little evidence of significant additive harvest mortality for pintails. More precise estimates of the process correlations could likely be achieved by increasing the number of pintails banded, thereby increasing the precision around the estimates of annual survival and recovery rates.

Our study shows a slight increase in survival rates of pintails from Prairie Canada over the period of time when the population experienced a significant decline. Because of the population decline, harvest regulation restrictions were imposed. However, we could find no clear evidence that restrictive hunting bag limits affected annual survival, recovery, or harvest rates of pintails from Prairie Canada. In addition, the abundance of pintails remained relatively stable in the latter half of the study, albeit considerably lower than in the first half, despite increases in harvest rates. If bag limits were to have their intended effect, one would expect harvest rates to decrease or remain low when restrictions were implemented and to increase or remain high under liberalization measures, but that trend was not apparent; rather, trends in harvest rates and total harvest appeared to track more closely the trends in the population. It is possible that harvest rates would have increased more dramatically from the late 1980s had restrictions been lifted, but there is currently no evidence to support that hypothesis. Because the population, total harvest, and harvest rates were all declining prior to implementation of bag limit restrictions, the effect of these restrictions may be confounded (Rice et al. 2010, Sedinger and Herzog 2012). Therefore, we are unable to rule out definitively an effect of restrictive hunting bag limits. Our results were specific to pintails banded in Prairie Canada, and it is possible that bag limit size may have a more pronounced effect on pintails in other regions. Nevertheless, Rice et al. (2010) found similar survival rates and little evidence to support the hypothesis that harvest regulations affect pintail survival and recovery rates at the continental scale.

Pintails in our study had higher survival rates and lower harvest rates than those reported for Mallard (Anas platyrhynchos; Anderson 1975, Smith and Reynolds 1992, Alisauskas et al. 2014), a similar species that has increased in abundance since the North American population lows of the 1980s. Given the relatively high and stable survival and low harvest rates, we surmise that there must be additional factors such as the production of young that caused the population decline and are preventing the population from returning to historically high levels. The declining age ratio of young to adult banded birds noted here may be an indication of decreased production but may also be a result of trap or site selection bias toward adults. The amount of land in Prairie Canada dedicated to agriculture has increased over time, but perhaps more significant to the population decline of pintails was a change in cropping practices (Bethke and Nudds 1995). Summerfallow, the practice of leaving land uncropped for a growing season, declined dramatically in Prairie Canada in the last quarter of the 20th century, when there was a shift to continuous annual cropping (Carlyle 1997). Pintails nest relatively early and do not avoid nesting in uplands with sparse cover, e.g., crop stubble from the previous year, to the same degree that other prairie nesting dabbling ducks do (Greenwood et al. 1995, Podruzny et al. 2002, Richkus et al. 2005). Therefore, pintails and their nests may be more vulnerable to spring seeding activities than other species of prairie ducks, leading to reduced nest success and overall productivity (Hestbeck 1995, Miller and Duncan 1999, Podruzny et al. 2002, Hebert and Wassenaar 2005). However, there are indications that widespread use of fall-seeded crops in Prairie Canada could improve nest success and the abundance of pintails (Devries et al. 2008, Skone et al. 2016).

Although current hunting bag limit restrictions appear to have had little to no measureable effect on annual survival and harvest rates, we cannot definitively rule out an effect because the impact of the restrictions was likely confounded by the population decline occurring at the same time of implementation (Rice et al. 2010, Sedinger and Herzog 2012). Furthermore, we could find no compelling evidence that harvest mortality was substantially additive to nonharvest mortality, but we acknowledge that there is some uncertainty in this finding because of the imprecision around our estimates of process correlations between annual survival and recovery rates. Consequently, we suggest that liberalization of bag limits for a trial period (e.g., 5-10 years) could do much to improve our understanding of the effects of the restrictions on the population. Currently, the population is relatively low but stable, and the effects of a change to bag limits could be more quantifiable and less cofounded than the late 1980s, when restrictions were implemented as the population was in a major decline (Rice et al. 2010). If, after the trial period, an evaluation were to reveal little evidence of the effect of bag limit liberalization, the liberalized bag limits could remain in place or be liberalized even further; restrictions could be reimplemented if a large negative effect of the liberalization were detected. Such an experiment would be considered active adaptive management (Sedinger and Herzog 2012), and we believe that it would do much to illustrate the effects of bag limit restrictions on harvest and population dynamics of pintails while posing little risk to the population over a short term. 
Current numbers of pintails banded must be maintained to produce the relatively precise estimates of survival, recovery, and harvest rates exhibited here. Monitoring of these population parameters can be especially important during periods of regulation changes or implementation of other conservation programs to determine the magnitude of potential effects. During periods when changes are implemented, higher numbers of pintails banded may be required to achieve more precise estimates, which could potentially allow for earlier detection of change. More precise estimates of annual survival and recovery rates would also lead to more precise estimates of the associated process correlations and would improve the assessment of whether harvest mortality is additive or compensatory to nonharvest mortality. We also recommend banding as many hatch-year pintails as possible but recognize that the presence of hatch-year pintails is difficult to predict because of highly variable annual production conditions. Studies over shorter time periods would require a higher number of pintails to be banded to achieve similar levels of precision as obtained here.

\section{CONCLUSION}

Annual survival rates of pintails from Prairie Canada were not starkly unique from those of pintails in other regions, and we could find no evidence of a decline in annual survival rates coinciding with the population decline, even though Prairie Canada was the region where the population decline was most pronounced. Rather, survival rates increased slightly over the study period. In addition, we could find no clear evidence of an effect of hunting bag limit restrictions on annual survival and harvest rates of pintails in Prairie Canada, but we suggest that more evaluation needs to be done before ruling out an effect of bag limit restrictions on these population parameters. An experiment of liberalized bag limits for pintails would do much to improve our understanding of harvest and population dynamics for the species and would help to validate or refute current bag limit restrictions while posing little risk to the population. An improved understanding of the effects of harvest regulations may highlight the value of imposing harvest restrictions in the event of future population declines. Imposing harvest restrictions can discourage participation in waterfowl hunting, which could ultimately prove more detrimental than good for waterfowl conservation if the benefits to the waterfowl population are negligible (Sedinger and Herzog 2012, Vrtiska et al. 2013). Alternatively, if there are clear, quantifiable, and documented benefits to pintails from harvest restrictions, then there could be more support and less opposition when restrictions are implemented in response to future population declines. Finally, given the relatively high and stable survival rates, we suggest that further efforts be taken to estimate the effects of agriculture on the production of pintails and to identify other potentially limiting factors to population growth such as disease. Based on our results and the current understanding of pintail population dynamics, we believe that measures other than harvest restrictions need be considered if we are to arrive at solutions that will return the population to the NAWMP objective.

Responses to this article can be read online at: http://www.ace-eco.org/issues/responses.php/1048

\section{Acknowledgments:}

This study would not have been possible without the efforts of hundreds of banders and thousands of hunters who applied and reported bands over the years of this study. Louise Laurin and the Canadian Bird Banding Office provided access to the banding data. Todd W. Arnold graciously provided instruction and advice on the use of MCMC analysis. This paper was greatly improved by the suggestions of Robert G. Clark, Joel Ingram, the ACE Subject Editor, and two anonymous reviewers on earlier versions of the manuscript.

\section{LITERATURE CITED}

Alisauskas, R. T., T. W. Arnold, J. O. Leafloor, D. L. Otis, and J. S. Sedinger. 2014. Lincoln estimates of mallard (Anas platyrhynchos) abundance in North America. Ecology and Evolution 4:132-143. http://dx.doi.org/10.1002/ece3.906

Alisauskas, R. T., K. L. Drake, and J. D. Nichols. 2009. Filling a void: abundance estimation of North American populations of arcitc geese using hunter recoveries. Pages 463-489 in D. L. Thomson, editor. Modelling demographic processes in marked populations. Springer, Boston, Massachusetts, USA. http://dx. doi.org/10.1007/978-0-387-78151-8_20

Alisauskas, R. T., R. F. Rockwell, K. W. Dufour, E. G. Cooch, G. Zimmerman, K. L. Drake, J. O. Leafloor, T. J. Moser, and E. T. Reed. 2011. Harvest, survival, and abundance of midcontinent lesser snow geese relative to population reduction efforts. Wildlife Monographs 179(1):1-42. http://dx.doi.org/10.1002/wmon.5

Anderson, D. R. 1975. Population ecology of the mallard: V. Temporal and geographic estimates of survival, recovery and harvest rates. Resource Publication 125. U.S. Fish and Wildlife Service, Washington, D.C., USA.

Anderson, D. R., and K. P. Burnham. 1976. Population ecology of the mallard: VI. The effect of exploitation on survival. U.S. Fish and Wildlife Service Resource Publication 128. U.S. Fish and Wildlife Service, Washington, D.C., USA.

Arnold, T. W., A. D. Afton, M. J. Anteau, D. N. Koons, and C. A. Nicolai. 2016. Temporal variation in survival and recovery rates of lesser scaup. Journal of Wildlife Management 80:850-861. http://dx.doi.org/10.1002/jwmg.21074

Baldassare, G. A. 2014. Ducks, geese, and swans of North America. Second edition. John Hopkins University Press, Baltimore, Maryland, USA.

Bethke, R. W., and T. D. Nudds. 1995. Effects of climate change and land use on duck abundance in Canadian prairie-parklands. Ecological Applications 5:588-600. http://dx.doi.org/10.2307/1941969

BirdLife International. 2016. Northern Pintail Anas acuta. BirdLife International, Cambridge, UK. [online] URL: http:// datazone.birdlife.org/species/factsheet/Northern-Pintail

Boomer, G. S., G. S. Zimmerman, N. L. Zimpfer, P. R. Garrettson, M. D. Koneff, T. A. Sanders, K. D. Magruder, and J. A. Royle. 2013. Band reporting probabilities for mallards recovered in the United States and Canada. Journal of Wildlife Management 77:1059-1066. http://dx.doi.org/10.1002/jwmg.570 
Brownie, C., D. R. Anderson, K. P. Burnham, and D. S. Robson. 1985. Statistical inference from band recovery data: a handbook. Resource Publication 156. U.S. Fish and Wildlife Service, Washington, D.C., USA. [online] URL: https://pubs.er.usgs.gov/ publication/rp156

Burnham, K. P., and D. R. Anderson. 2002. Model selection and multimodel inference: a practical information-theoretic approach. Second edition. Springer, New York, New York, USA. http://dx. doi.org/10.1007/b97636

Carlyle, W. J. 1997. The decline of summerfallow on the Canadian Prairies. Canadian Geographer 41:267-280. http://dx.doi. org/10.1111/j.1541-0064.1997.tb01313.x

Clark, R. G., J. P. Fleskes, K. L. Guyn, D. A. Haukos, J. E. Austin, and M. R. Miller. 2014. Northern Pintail (Anas acuta). In Birds of North America. American Ornithological Society and Cornell Lab of Ornithology, Ithaca, New York, USA. [online] URL: https://birdsna.org/Species-Account/bna/species/norpin

Cooch, E. G., M. Guillemain, G. S. Boomer, J. D. Lebreton, and J. D. Nichols. 2014. The effects of harvest on waterfowl populations. Wildfowl Special Issue 4:220-276. [online] URL: http://wildfowl.wwt.org.uk/index.php/wildfowl/article/view/2608

Cox, R. R. Jr., and A. D. Afton. 1998. Effects of capture and handling on survival of female Northern Pintails. Journal of Field Ornithology 69:276-287.

Devries, J. H., L. M. Armstrong, R. J. Macfarlane, L. Moats, and P. T. Thoroughgood. 2008. Waterfowl nesting in fall-seeded and spring-seeded cropland in Saskatchewan. Journal of Wildlife Management 72:1790-1797. http://dx.doi.org/10.2193/2007-513

Dieter, C. D., R. J. Murano, and D. Galster. 2009. Capture and mortality rates of ducks in selected trap types. Journal of Wildlife Management 73:1223-1228. http://dx.doi.org/10.2193/2008-438

Dufour, K. W., and R. G. Clark. 2002. Differential survival of yearling and adult female mallards and its relation to breeding habitat conditions. Condor 104:297-308. http://dx.doi. org/10.1650/0010-5422(2002)104[0297:DSOYAA]2.0.CO;2

Fleskes, J. P., J. L. Yee, G. S. Yarris, M. R. Miller, and M. L. Casazza. 2007. Pintail and mallard survival in California relative to habitat, abundance, and hunting. Journal of Wildlife Management 71:2238-2248. http://dx.doi.org/10.2193/2005-634

Flint, P. L., J. B. Grand, and R. F. Rockwell. 1998. A model of northern pintail productivity and population growth rate. Journal of Wildlife Management 62:1110-1118. http://dx.doi.org/10.2307/3802565

Gendron, M. H., and A. C. Smith. 2016. National harvest survey data. National Wildlife Research Centre, Canadian Wildlife Service, Ottawa, Canada. [online] URL: http://www.ec.gc.ca/ reom-mbs/enp-nhs/index.cfm?do=def\&lang=e

Greenwood, R. J., A. B. Sargeant, D. H. Johnson, L. M. Cowardin, and T. L. Shaffer. 1995. Factors associated with duck nest success in the Prairie Pothole region of Canada. Wildlife Monographs 128:1-57.

Hebert, C. E., and L. I. Wassenaar. 2005. Stable isotopes provide evidence for poor northern pintail production on the Canadian Prairies. Journal of Wildlife Management 69:101-109. http://dx. doi.org/10.2193/0022-541X(2005)069<0101:SIPEFP>2.0.CO;2
Hestbeck, J. B. 1995. Response of northern pintail breeding populations to drought, 1961-1992. Journal of Wildlife Management 59:9-15. http://dx.doi.org/10.2307/3809109

Johnson, D. H., J. D. Nichols, and M. D. Schwartz. 1992. Population dynamics of breeding waterfowl. Pages 446-485 in B. D. J. Batt, A. D. Afton, M. G. Anderson, C. D. Ankney, D. H. Johnson, J. A. Kadlec, and G. L. Krapu, editors. Ecology and management of breeding waterfowl. University of Minnesota Press, Minneapolis, Minnesota, USA.

Kramer, G. W. 1995. Waterfowl harvest and hunting activity in Mexico. North American Wildlife and Natural Resources Conference Transactions 60:243-250.

Lebreton, J.-D., K. P. Burnham, J. Clobert, and D. R. Anderson. 1992. Modeling survival and testing biological hypotheses using marked animals: a unified approach with case studies. Ecological Monographs 62:67-118. http://dx.doi.org/10.2307/2937171

Miller, M. R., and D. C. Duncan. 1999. The northern pintail in North America: status and conservation needs of a struggling population. Wildlife Society Bulletin 27:788-800.

Nichols, J. D., R. S. Pospahala, and J. E. Hines. 1982. Breedingground habitat conditions and the survival of mallards. Journal of Wildlife Management 46:80-87. http://dx.doi.org/10.2307/3808410

Nicolai, C. A., P. L. Flint, and M. L. Wege. 2005. Annual survival and site fidelity of northern pintails banded on the YukonKuskokwim Delta, Alaska. Journal of Wildlife Management 69:1202-1210. http://dx.doi.org/10.2193/0022-541X(2005)069[1202: ASASFO]2.0.CO;2

North American Waterfowl Management Plan. 2014. Revised objectives: an addendum to the 2012 North American Waterfowl Management Plan. North American Waterfowl Management Plan. [online] URL: https://nawmp.org/sites/default/files/ NAWMP_Revised_Objectives_North_American_Waterfowl_Management_Plan_Final_9-22-14.pdf

Otis, D. L., and G. C. White. 2004. Evaluation of ultrastructure and random effects band recovery models for estimating relationships between survival and harvest rates in exploited populations. Animal Biodiversity and Conservation 27:157-173.

Podruzny, K. M., J. H. Devries, L. M. Armstrong, and J. J. Rotella. 2002. Long-term response of northern pintails to changes in wetlands and agriculture in the Canadian Prairie Pothole region. Journal of Wildlife Management 66:993-1010. http://dx.doi. org/10.2307/3802932

Rice, M. B., D. A. Haukos, J. A. Dubovsky, and M. C. Runge. 2010. Continental survival and recovery rates of northern pintails using band-recovery data. Journal of Wildlife Management 74:778-787. http://dx.doi.org/10.2193/2008-598

Richkus, K. D., F. C. Rohwer, and M. J. Chamberlain. 2005. Survival and cause-specific mortality of female northern pintails in southern Saskatchewan. Journal of Wildlife Management 69:574-581. http://dx.doi.org/10.2193/0022-541X(2005)069[0574: SACMOF]2.0.CO;2

Royle, J. A., and P. R. Garrettson. 2005. The effect of reward band value on mid-continent mallard band reporting rates. Journal of Wildlife Management 69:800-804. http://dx.doi.org/10.2193/0022-541X (2005)069[0800:TEORBV]2.0.CO;2 
Sedinger, J. S., and M. P. Herzog. 2012. Harvest and dynamics of duck populations. Journal of Wildlife Management 76:1108-1116. http://dx.doi.org/10.1002/jwmg.370

Sedinger, J. S., G. C. White, S. Espinosa, E. T. Partee, and C. E. Braun. 2010. Assessing compensatory versus additive harvest mortality: an example using greater sage-grouse. Journal of Wildlife Management 74:326-332. http://dx.doi.org/10.2193/2009-071

Skone, B. R., J. J. Rotella, and J. Walker. 2016. Waterfowl production from winter wheat fields in north and south Dakota. Journal of Wildlife Management 80:127-137. http://dx.doi. org/10.1002/jwmg.993

Smith, G. W. 1995. A critical review of the aerial and ground surveys of breeding waterfowl in North America. Biological Science Report 5. U.S. Fish and Wildlife Service, Washington, D.C., USA.

Smith, G. W., and R. E. Reynolds. 1992. Hunting and mallard survival, 1979-88. Journal of Wildlife Management 56:306-316. http://dx.doi.org/10.2307/3808827

U.S. Fish and Wildlife Service. 2016. Harvest trends. Flyways.us, U.S. Fish and Wildlife Service, Washington, D.C., USA. [online] URL: http://flyways.us/regulations-and-harvest/harvest-trends

Vrtiska, M. P., J. H. Gammonley, L. W. Naylor, and A. H. Raedeke. 2013. Economic and conservation ramifications from the decline of waterfowl hunters. Wildlife Society Bulletin 37:380-388. http://dx.doi.org/10.1002/wsb.245

White, G. C., and K. P. Burnham. 1999. Program MARK: survival estimation from populations of marked animals. Bird Study 46 (S1):120-139. http://dx.doi.org/10.1080/00063659909477239 